\title{
Tinjauan Pelaksanaan Review Berkas Rekam Medis Sesuai Standar Manajemen Informasi Dan Rekam Medik (MIRM 13.4) Di Rumah Sakit Imelda Pekerja Indonesia Tahun 2020
}

\author{
Esraida Simanjuntak ${ }^{1}$, Mustamil Alwi Dasopang ${ }^{2}$ \\ 1,2Program Studi D-3 Perekam dan Informasi Kesehatan, Universitas Imelda Medan
}

\section{Article Info}

\section{Article history:}

Received Dec 31, 2020

Revised Jan 11, 2021

Accepted Feb 17, 2021

\section{Keywords:}

Review

Medical Record Files

Medical Record Information

Management (MIRM) 13.4

\begin{abstract}
ABSTRAK
One of the parameters for determining the quality of health services in the hospital is data or information from good and complete medical records. Medical records are an important part of helping the implementation of service delivery to patients at the hospital. Standards relating to medical records in SNARS Edition 1 are in the group of hospital management standards, namely Medical Record Information Management (MIRM) regarding medical record document processing including provision, filling of medical records and reviewing medical records. This research method is descriptive with the method of observation. When this research was conducted in July 2020 at the Imelda Hospital Worker Indonesia Medan. The population taken was 705 medical record documents while the sample in this study was 87 medical record documents. Based on the results of the study, in the review the accuracy of returning medical record documents was $57.4 \%$ and $42.5 \%$ were incorrect. Readability review of ER assessment as much as $63.2 \%$, assessment of Inpatient as much as $56.3 \%$, CPPT as much as $60.9 \%$, approval for action as much as $77 \%$, reports of anesthesia as much as $68.9 \%$. 3 forms of completeness review are complete, namely Education Assessment, rejection and education form (100\%). Suggestions in this study are that review officers must be more assertive to remind every doctor or other medical personnel to pay attention to the accuracy of the restoration, the legibility of medical record files and the completeness of medical record documents. As well as regularly socializing the elements of the MIRM 13.4 assessment.
\end{abstract}

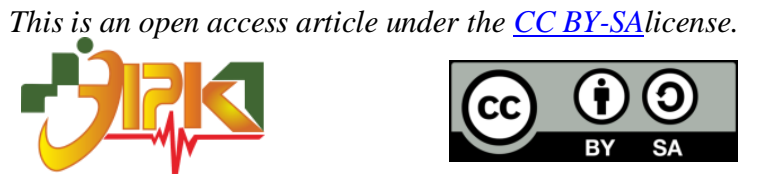

Corresponding Author:

Esraida Simanjuntak,

Program Studi D-3 Perekam dan Informasi Kesehatan,

Universitas Imelda Medan,

Jl. Bilal No. 52 Kelurahan Pulo Brayan Darat I Kecamatan Medan Timur, Medan - Sumatera Utara.

Email: esraida.borjun@gmail.com

\section{PENDAHULUAN}

Rumah sakit adalah institusi pelayanan kesehatan perorangan secara paripurna yang menyediakan rawat inap, rawat jalan dan gawat darurat (Permenkes RI No.3/MENKES/PER/2020). Salah satu parameter untuk menentukkan mutu pelayanan kesehatan di rumah sakit adalah data atau informasi dari rekam medis yang baik dan 
lengkap. Rekam medis merupakan salah satu bagian penting dalam membantu pelaksanaan pemberian pelayanan kepada pasien di Rumah Sakit. Hal ini berkaitan dengan isi rekam medis yang mencerminkan segala informasi menyangkut pasien sebagai dasar dalam menentukan tindakan lebih lanjut dalam upaya pelayanan maupun tindakan medis lain. Menurut Permenkes No. 269/Menkes/Per/III/2008 tentang rekam medis, Rekam medis adalah berkas yang berisikan catatan dan dokumen tentang identitas pasien, pemeriksaan, pengobatan, tindakan dan pelayanan lain yang telah diberikan kepada pasien.

Di era globalisasi ini, rumah sakit perlu terus meningkatan mutu layanan dan keselamatan pasien secara berkesinambungan dan berkelanjutan. Peningkatan mutu dan keselamatan pasien merupakan proses kegiatan yang tidak pernah berhenti dan harus selalu dilakukan oleh rumah sakit di Indonesia, sehingga dapat sejajar dengan mutu rumah sakit di tingkat internasional. Dalam rangka meningkatkan mutu pelayanan, rumah sakit wajib diakreditasi secara berkala minimal 3 (tiga) tahun sekali, sesuai amanah Undang-Undang Nomor 44 Tahun 2009 tentang rumah sakit. Tujuan pengaturan akreditasi adalah untuk meningkatkan mutu pelayanan rumah sakit dan melindungi keselamatan pasien, meningkatkan perlindungan bagi masyarakat, sumber daya manusia di rumah sakit dan rumah sakit sebagai institusi, mendukung program pemerintah di bidang kesehatan dan meningkatkan profesionalisme rumah sakit Indonesia di mata Internasional.

Dalam melaksanakan akreditasi rumah sakit, lembaga independen pelaksana akreditasi rumah sakit wajib menetapkan standar akreditasi yang dipergunakan untuk melakukan penilaian akreditasi. Standar akreditasi secara berkala perlu di review dan ditingkatkan sejalan dengan perkembangan standar akreditasi internasional. Berdasarkan UndangUndang No.34 Tahun 2017 pasal 1 ayat I tentang akreditasi rumah sakit menyebutkan bahwa akreditasi rumah sakit yang selanjutnya disebut akreditasi adalah pengakuan terhadap mutu pelayanan rumah sakit, setelah dilakukan penilaian bahwa rumah sakit telah memenuhi standart akreditasi. Standar yang berkaitan dengan rekam medis dalam SNARS Edisi 1 terdapat pada kelompok standar manajemen rumah sakit yaitu manajemen informasi rekam medis mengenai pengolahan dokumen rekam medis meliputi penyedian, pengisian rekam medis dan review rekam medis.

Kelengkapan rekam medis sangat penting mengingat rekam medis memiliki banyak kegunaan diantaranya karena di dalamnya memuat informasi perkembangan kronologis penyakit, pelayanan medis, pengobatan dan tindakan medis, bermanfaat untuk bahan informasi bagi perkembangan pengajaran, penelitian termasuk di di bidang manajemen rumah sakit. Ketidaklengkapan pada rekam medis dapat mengakibatkan tertundanya pelaporan dan juga apabila ada pasien yang meminta dibuatkan surat keterangan medis jadi tertunda karena harus meminta dokter yang merawat untuk melengkapi dokumen rekam medis rawat inap tersebut.

Berdasarkan hasil penelitian (Linda Widyaningrum, 2017) dengan judul Analisis Pengolahan Dokumen Rekam medis Rawat Inap Berdasarkan (SNARS) Edisi 1 Di RSJD dr. Arip Zainudin Surakarta adalah pelaksanaan review rekam medis berdasarkan SNARS Edisi 1 standar MIRM 13.4 di RSJD dr. Arif Zainudin rumah sakit menetapkan individu atau tim yang melakukan review rekam medis secara berkala yang melakukan review rekam medis diatur dalam kebijakan pelayanan rekam medis RSJD Surakarta yang menyebutkan pelaksanaan review dokumen rekam medis, instalasi rekam medis menggunakan kouta sampling dalam pelaksanaan review dokumen rekam medis, sampel yang digunakan setiap triwulannya sejumlah 50 sampel dokumen rekam medis serta evaluasi dan monitoring terhadap review dokumen rekam medis dilakukan oleh para pemberi asuhan secara berkala dengan menggunakan sampel yang dilakukan oleh komite medik dan komite keperawatan tentang ketepatan waktu, kelengkapan dapat terbaca. Pelaksanakan review rekam medis Berdasarkan (SNARS) Edisi 1 Di RSJD dr. Arip 
zainudin Surakarta mengenai proses review termasuk isi rekam medis harus sesuai dengan peraturan dan perundang-undangan terpenuhi lengkap sesuai instrument akreditasi rumah sakit berdasarkan SNARS Edisi 1.

Berdasarkan penelitian sebelumnya oleh (Simanjuntak \& Napitupulu, 2019) dalam penelitiannya yang berjudul Analisis Ketidaklengkapan Dokumen Rekam Medis Menurut Standar Akreditasi Rumah Sakit MKI 19.1 Versi KARS 2012 Di Rumah Sakit Imelda pekerja Indonesia (RSU IPI) Medan tahun 2018 dari jumlah berkas yang dilakukan pada bulan Juni 2018 jumlah populasi dalam penelitian yaitu 81 berkas rekam medis pasien pulang dengan kelengkapan $66,67 \%$ pada formulir dokumen pemeriksaan dan formulir ketidaklengkapan 69,14\% pada indentifikasi pasien, adapun ketidaklengkapan dokumen rekam medis ini diakibatkan oleh petugas rekam medis dan perawat ruangan yang masih kurang efektif dalam pemantauan perawat maupun dokter masih sering lupa untuk mengisi berkas rekam medis secara lengkap dan kesibukan dokter serta perawat dalam menangani pasien.

Menurut (Badra Al Aufa, 2018) dalam penelitiannya menyebutkan bahwa Faktor Yang Berpengaruh Terhadap Ketidaktepatan Waktu Pengembalian Berkas Rekam Medis Rawat Inap Di RS X Bogor merupakan salah satu unsur yang mempengaruhi kualitas kinerja unit rekam medis, standar waktu pengembalian $2 \times 24$ jam setelah pasien pulang, diketahui persentase pengembalian berkas rekam medis dalam jangka waktu $>2 \times 24$ jam sebesar $65,54 \%$. Adapun faktor- faktor yang mempengaruhi keterlambatan pengembalian berkas rekam medis ialah keterbatasan jumlah petugas pelaksana, jarak antar gedung pelayanan rawat inap dan rekam medis yang cukup jauh, serta belum adanya sosialisasi SPO secara memadai.

Hasil survey awal ditemukan bahwa di RSU Imelda Pekerja Indonesia review berkas rekam medis tentang kelengkapan formulir rekam medis, ketepatan pengembalian rekam medis, keterbacaan rekam medis masih ada sebagian belum terlaksana. Dikarenakan masih banyak dijumpai berkas rekam medis yang kurang memenuhi karakteristik tersebut terutama pada masalah kelengkapan formulir rekam medis, ketepatan pengembalian rekam medis dan keterbacaan berkas rekam medis.

\section{METODE PENELITIAN}

A. Jenis Penelitian

Jenis penelitian yang digunakan adalah penelitian deskriptif yaitu suatu metode penelitian yang dilakukan dengan tujuan untuk mendeskripsikan tentang suatu keadaan secara objektif (Notoatmojo, 2017). Jenis penelitian ini digunakan untuk mengetahui gambaran pelaksanaan review berkas rekam medis sesuai Standar Manajemen Informasi dan Rekam Medik (MIRM 13.4) di RSU Imelda Pekerja Indonesia Tahun 2020.

B. Populasi

Populasi menurut (Sugiyono, 2018), yaitu wilayah generalisasi yang terdiri atas objek/subjek yang mempunyai kualitas dan karakteristik yang ditetapkan oleh peneliti untuk dipelajari dan kemudian ditarik kesimpulannya. Dalam penelitian ini populasi yang diambil adalah seluruh berkas rekam medis yang digunakan di unit rawat inap pada bulan Mei yang berjumlah 705 dokumen rekam medis.

C. Sampel

Perhitungan Sampel Dengan Menggunakan Rumus Slovin

$\mathrm{n}=\frac{N}{1+N(d)^{2}}$

$\mathrm{n}=\frac{705}{1+705(0.1)^{2}}$ 


$$
\begin{aligned}
& \mathrm{n}=\frac{705}{1+7.05} \\
& \mathrm{n}=\frac{705}{8.05} \\
& \mathrm{n}=87 \text { berkas rekam medis }
\end{aligned}
$$

Sampel penelitian berupa berkas rekam medis yang berada di Rumah Sakit Imelda Pekerja Indonesia. Jumlah sampel berkas rekam medis yang digunakan adalah 87 berkas rekam medis rawat inap yang dipilih berdasarkan Simple Random sampling.

D. Instrumen Penelitian

Instrumen yang digunakan dalam penelitian ini adalah Observasi Atau Pengamatan.

E. Cara Pengumpulan Data

Cara pengumpulan data yang digunakan adalah Studi Observasi, dimana peneliti mengamati langsung pada review berkas rekam medis, kemudian mencatat hasil yang diamati dengan menggunakan alat tulis yang dibutuhkan.

F. Analisis Data

Analisis data merupakan metode untuk mengukur hasil penelitian. Analisis dalam penelitian ini adalah analisis deskriptif yaitu membandingkan teori terhadap pelaksanaan review berkas rekam medis sesuai Standar Manajemen Informasi dan Rekam Medik (MIRM 13.4) di RSU Imelda Pekerja Indonesia Tahun 2020.

\section{HASIL DAN PEMBAHASAN}

\subsection{Hasil}

Berdasarkan hasil penelitian oleh peneliti yang berjudul "Tinjauan Pelaksanaan Review Berkas Rekam Medis Sesuai Standar Manajemen Informasi Dan Rekam Medik (MIRM 13.4) Di Rumah Sakit Imelda Pekerja Indonesia Tahun 2020". Adapun data yang diambil pada bulan Mei tahun 2020 sehingga diperoleh hasil sebagai berikut:

Tabel 1. Review Ketepatan Pengembalian

\begin{tabular}{lcc}
\hline Variabel Ketepatan Pengembalian (2x24 jam) & F & $\mathbf{( \% )}$ \\
\hline Tepat & 50 & $57,4 \%$ \\
\hline Tidak Tepat & 37 & $42,5 \%$ \\
\hline Total & $\mathbf{8 7}$ & $\mathbf{1 0 0 \%}$ \\
\hline
\end{tabular}

Dari tabel diatas dilihat bahwa dari 87 BRM yang direview yang tepat pengembalian ada sebanyak $57.4 \%$ yaitu $50 \mathrm{BRM}$, dan yang tidak tepat pengembaliannya sebanyak $42.5 \%$ yaitu 37 BRM.

Tabel 2. Review Keterbacaan Berkas Rekam Medis

\begin{tabular}{lcccc}
\hline $\begin{array}{c}\text { Variabel Keterbacaan } \\
\text { rekam medis }\end{array}$ & $\begin{array}{c}\text { Frekuensi } \\
\text { Terbaca }\end{array}$ & $\mathbf{( \% )}$ & $\begin{array}{c}\text { Frekuensi Tidak } \\
\text { Terbaca }\end{array}$ & $\mathbf{( \% )}$ \\
\hline Assesmen Igd & 55 & $63.2 \%$ & 32 & $36.7 \%$ \\
\hline Assesmen Rawat inap & 49 & $56.3 \%$ & 38 & $43.6 \%$ \\
\hline CPPT & 53 & $60.9 \%$ & 34 & $39 \%$ \\
\hline Persetujuan tindakan & 67 & $77 \%$ & 20 & $22.9 \%$ \\
\hline Laporan anestesi & 60 & $68.9 \%$ & 27 & $31 \%$ \\
\hline Total & $\mathbf{8 7}$ & $\mathbf{1 0 0 \%}$ & $\mathbf{8 7}$ & $\mathbf{1 0 0 \%}$ \\
\hline
\end{tabular}

Dari tabel diatas dapat dilihat bahwa dari 87 BRM yang direview terdiri dari Assesmen Igd, Assesmen Rawat Inap, CPPT, persetujuan tindakan, laporan anestesi yang terbaca yaitu: Assesmen Igd sebanyak 63.2\% (55 BRM), Assesmen Rawat Inap sebanyak $56.3 \%$ (49 BRM), CPPT sebanyak 60.9\% (53 BRM), persetujuan tindakan sebanyak 77\% (67 BRM), laporan anestesi sebanyak 68.9\% (60 BRM), sedangkan yang tidak terbaca 
yaitu: Assesmen Igd sebanyak 36.7\% (32 BRM), Assesmen Rawat Inap sebanyak $43.6 \%$ (38 BRM), CPPT 39\% (34 BRM), persetujuan tindakan sebanyak 22.9\% (20 BRM), laporan anestesi sebanyak 31\% (27 BRM).

Tabel 3. Review Kelengkapan Berkas Rekam Medis

\begin{tabular}{lcccc}
\hline $\begin{array}{c}\text { Variabel Kelengkapan } \\
\text { Formulir }\end{array}$ & $\begin{array}{c}\text { Frekuensi } \\
\text { Lengkap }\end{array}$ & $\mathbf{( \% )}$ & $\begin{array}{c}\text { Frekuensi } \\
\text { Tidak Lengkap }\end{array}$ & $\mathbf{( \% )}$ \\
\hline Triage & 60 & $68.9 \%$ & 27 & $31 \%$ \\
\hline Assesmen Igd & 53 & $60.9 \%$ & 34 & $39 \%$ \\
\hline Assesmen Edukasi & 87 & $100 \%$ & - & - \\
\hline CPPT & 50 & $57.4 \%$ & 37 & $42.5 \%$ \\
\hline Catatan Perawat & 51 & $58.6 \%$ & 16 & $18.3 \%$ \\
\hline Informed Consent & 65 & $74.7 \%$ & 22 & $25.2 \%$ \\
\hline Penolakan & 87 & $100 \%$ & - & - \\
\hline Form Edukasi & 87 & $100 \%$ & - & - \\
\hline Resume & 52 & $59.7 \%$ & 35 & $40.2 \%$ \\
\hline Transfer & 55 & $63.2 \%$ & 32 & $36.7 \%$ \\
\hline Total & $\mathbf{8 7}$ & $\mathbf{1 0 0 \%}$ & $\mathbf{8 7}$ & $\mathbf{1 0 0 \%}$ \\
\hline
\end{tabular}

Dari tabel diatas dilihat bahwa dari 87 BRM yang di review terdiri dari formulir triage, Assesmen IGD, Assesmen Edukasi, CPPT, catatan perawat, informed consent, penolakan, form edukasi, resume, transfer. Yang mencapai lengkap ada sebanyak 3 formulir yaitu Assesmen Edukasi, penolakan, form edukasi (100\%). Dan yang tidak lengkap yaitu formulir triage 31\% (27 BRM), Assesmen Edukasi 39\% (34 BRM), CPPT 42.5\% (37 BRM), catatan perawat 18.3\% (16 BRM), informed consent 25.2\% (22 BRM), Resume $40.2 \%$ (35 BRM), transfer 36.7\% (32 BRM).

\subsection{Pembahasan}

\section{Review Ketepatan Pengembalian}

Berdasarkan hasil penelitian menunjukkan bahwa ketepatan pengembalian berkas rekam medis di RSU Imelda Pekerja Indonesia dari 87 berkas rekam medis rawat inap masih terjadi ketidaktepatan waktu pengembalian berkas rekam medis yang terjadi sebesar 37 berkas rekam medis atau $42.5 \%$ dan yang tepat waktu pengembalian sebesar 50 berkas rekam medis atau $57.4 \%$. Berkas rekam medik paling lambat $2 \times 24$ jam setelah pasien keluar rumah sakit sesuai bedasarkan dengan SPO. Adapun faktor penyebab keterlambatan waktu pengembalian berkas rekam medis yaitu:

1. Kurangnya informasi yang terkait standar waktu pengembalian rekam medis rawat inap kepada petugas perawat ketahui, bahwa lebih cepat lebih baik bila rekam medis pasien rawat inap langsung dikembalikan ke unit rekam medis.

2. Belum terlengkapinya pengisian beberapa formulir rekam medis oleh dokter seperti diagnosa pada resume medis.

3. Kurangnya tanda tangan dokter pada formulir catatan perkembangan pasien terintegrasi.

\section{Review Keterbacaan Berkas Rekam Medis}

Untuk keterbacaan rekam medis menjelaskan bahwa terjadi ketidakterbacaan sebanyak: Assesmen Igd sebanyak 36.7\% (32 BRM), Assesmen Rawat Inap sebanyak 43.6\% (38 BRM), CPPT 39\% (34 BRM), persetujuan tindakan sebanyak 22.9\% (20 BRM), laporan anestesi sebanyak 31\% (27 BRM). Dalam permenkes 269 tahun 2008 tentang rekam medis bahwa rekam medis harus dibuat secara tertulis, lengkap dan jelas atau secara elektronik. Serta dalam hal terjadi kesalahan dalam melakukan pencatatan pada rekam 
medis dapat melakukan pembetulan, pembetulan sebagaimana dimaksud hanya dapat hanya dapat dilakukan dengan cara pencoretan tanpa menghilangkan catatan yang dibetulkan dan dibubuhi paraf dokter, dokter gigi, atau tenaga kesehatan tertentu yang bersangkutan.

\section{Review Kelengkapan Berkas Rekam Medis}

Untuk kelengkapan formulir menunjukan bahwa formulir berkas rekam medis masih terjadi ketidaklengkapan yaitu terdapat pada formulir triage 31\% (27 BRM), Assesmen edukasi 39\% (34 BRM), CPPT 42.5\% (37 BRM), catatan perawat 18.3\% (16 BRM), informed consent 25.2\% (22 BRM), resume 40.2\% (35 BRM), transfer 36.7\% (32 BRM). Dalam permenkes 269 tahun 2008 tentang rekam medis dijelaskan bahwa setiap dokter atau dokter gigi dalam menjalankan praktik kedokteran wajib membuat rekam medis dan harus dilengkapi setelah pasien selesai menerima pelayanan kesehatan. Setiap catatan rekam medis harus dibubuhi nama, tanda tangan petugas yang memberikan pelayanan dan tindakan.

\section{KESIMPULAN}

Berdasarkan penelitian yang peneliti lakukan maka memperoleh kesimpulan yaitu:

1. Pada review yang ketepatan pengembalian ada sebanyak $57.4 \%$ yaitu 50 BRM, dan yang tidak tepat pengembaliannya sebanyak $42.5 \%$ yaitu 37 BRM.

2. Pada review keterbacaan formulir rekam medis terdiri dari Assesmen Igd, Assesmen Rawat Inap, CPPT, persetujuan tindakan, laporan anestesi yang terbaca yaitu: Assesmen Igd sebanyak 63.2\% (55 BRM), assesmen Rawat Inap sebanyak 56.3\% (49 BRM), CPPT sebanyak 60.9\% (53 BRM), persetujuan tindakan sebanyak 77\% (67 BRM), laporan anestesi sebanyak 68.9\% (60 BRM).

3. Pada review kelengkapan formulir rekam medis terdiri dari formulir triage, assesmen IGD, assesmen Edukasi, CPPT, catatan perawat, informed consent, penolakan, form edukasi, resume, transfer. Yang mencapai lengkap ada sebanyak 3 formulir yaitu Assesmen Edukasi, penolakan, form edukasi (100\%).

\section{REFERENCES}

Simanjuntak, E., \& Napitupulu, B. (2019). Analisis Ketidaklengkapan Dokumen Rekam Medis Menurut Standar Akreditasi Rumah Sakit Mki 19.1 Versi Kars 2012 Di Rumah Sakit Umum Imelda Pekerja Indonesia (RSU IPI) Medan Tahun 2018. Jurnal Ilmiah Perekam Dan Informasi Kesehatan, 4(1), 533-536. http://jurnal.uimedan.ac.id/index.php/JIPIKI/article/view/73

Kementrian Kesehatan RI. 2020. Peraturan Menteri Kesehatan RI Nomor 3 tahun 2020 tentang klasifikasi dan perizinan rumah sakit. Jakarta: Kemenkes RI.

Kementrian Kesehatan RI. 2008. Peraturan Menteri Kesehatan RI Nomor 269 tahun 2008 tentang Rekam Medis. Jakarta: Kemenkes RI.

Kementrian Kesehatan RI. 2015. Peraturan Kementrian Kesehatan RI Nomor 46 tahun 2015 tentang Akreditasi Puskesmas, Klinik Pratama, Tempat praktik Mnadi Dokter, dan Tempat Praktik Mandiri Dokter Gigi. Jakarta: Kemenkes RI.

Komite Akreditasi Rumah Sakit. 2017. Standar Nasional Akreditasi Rumah Sakit Edisi 1. Jakarta. 
Notoatmodjo. 2010. Pendidikan dan Perilaku Kesehatan. Jakarta: Rineka Cipta.

Notoatmodjo. 2012. Metode penelitian kesehatan. Jakarta: Rineka Cipta.

Sugiyono. 2018. Metode Penelitian Pendidikan Pendekatan Kuantitatif, kualitatif dan $R \& D$. Bandung: Alpabeta.

Undang- Undang RI. 2017. Undang-Undang RI Nomor 34 tahun 2017 tentang Akreditasi Rumah Sakit. Jakarta: Undang-Undang Republik Indonesia.

Widyaningrum L. 2019. Analisis Pengelolaan Dokumen Rekam Medis Rawat Inap Berdasarkan (SNARS) Edisi 1 di RSJD DR. Arif Zainudin Surakarta. (dalam jurnal ilmiah Program Studi D3 Rekam Medik dan Informasi Kesehatan Universitas Duta Bangsa Surakarta tahun 2019) diakses tanggal 28 mei 2020.

\section{BIOGRAPHIES OF AUTHORS}

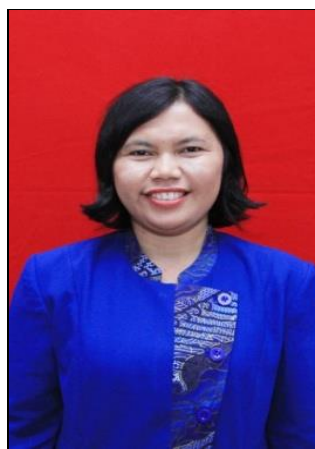

Esraida Simanjuntak, Gelar D-III diperoleh dari Akademi Keperawatan Pemkab Tapanuli Utara, Jurusan Keperawatan pada tahun 2006, Gelar Sarjana diperoleh dari Universitas Sumatera Utara, Fakultas Kesehatan Masyarakat tahun 2009, Magister Kesehatan diperoleh dari Universitas Sumatera Utara, jurusan Ilmu Kesehatan Masyarakat pada tahun 2017. Saat ini aktif sebagai dosen tetap di Prodi D-III Perekam dan Informasi Kesehatan Universitas Imelda Medan dan menjabat sebagai sekretaris Prodi. 